\title{
Intracellular Cross Talk and Physical Interaction between Two Classes of Neurotransmitter-Gated Channels
}

\author{
Éric Boué-Grabot, ${ }^{1,4 *}$ Carlos Barajas-López, ${ }^{2 *}$ Yassar Chakfe, ${ }^{1}$ Dominique Blais, ${ }^{1}$ Danny Bélanger, ${ }^{1}$ Michel B. Émerit, ${ }^{3}$ \\ and Philippe Séguéla ${ }^{1}$ \\ ${ }^{1}$ Montreal Neurological Institute, Department of Neurology and Neurosurgery, McGill University, Montreal, Quebec, Canada H3A 2B4, ${ }^{2}$ Department of Cell \\ Biology and Anatomy, Queen's University, Kingston, Ontario, Canada K7L 3N6, ${ }^{3}$ Institut National de la Santé et de la Recherche Médicale U288, Pitié- \\ Salpêtrière, 75013 Paris, France, and ${ }^{4}$ Centre National de la Recherche Scientifique Unité Mixte de Recherche 5543, Université Victor Segalen Bordeaux 2 , \\ 33076 Bordeaux cedex, France
}

Fast chemical communications in the nervous system are mediated by several classes of receptor channels believed to be independent functionally and physically. We show here that concurrent activation of $\mathrm{P} 2 \mathrm{X}_{2} \mathrm{ATP}$-gated channels and 5- $\mathrm{HT}_{3}$ serotonin-gated channels leads to functional interaction and nonadditive currents ( $47-73 \%$ of the predicted sum) in mammalian myenteric neurons as well as in Xenopus oocytes or transfected human embryonic kidney (HEK) 293 cell heterologous systems. We also show that these two cation channels coimmunoprecipitate constitutively and are associated in clusters. In heterologous systems, the inhibitory cross talk between $\mathrm{P} 2 \mathrm{X}_{2}$ and $5-\mathrm{HT}_{3}$ receptors is disrupted when the intracellular C-terminal domain of the $\mathrm{P} 2 \mathrm{X}_{2}$ receptor subunit is deleted and when minigenes coding for $\mathrm{P}_{2} \mathrm{X}_{2}$ or $5-\mathrm{HT}_{3} \mathrm{~A}$ receptor subunit cytoplasmic domains are overexpressed. Injection of fusion proteins containing the C-terminal domain of $\mathrm{P} 2 \mathrm{X}_{2}$ receptors in myenteric neurons also disrupts the functional interaction between native $\mathrm{P}_{2} \mathrm{X}_{2}$ and 5- $\mathrm{HT}_{3}$ receptors. Therefore, activity-dependent intracellular coupling of distinct receptor channels underlies ionotropic cross talks that may significantly contribute to the regulation of neuronal excitability and synaptic plasticity.

Key words: P2X purinoceptor; ATP; 5- $\mathrm{HT}_{3}$; serotonin; ionotropic; ligand-gated cation channel; myenteric neurons

\section{Introduction}

Fast communication in the nervous system is critical for information processing and synaptic plasticity; it is achieved through the activation of neurotransmitter-gated channels or ionotropic receptors (Sakmann, 1992) believed to be independent functionally and physically. The four known, structurally distinct classes of neurotransmitter-gated channels are represented by P2X ATPgated receptors (Khakh et al., 2001), Phe-Met-Arg-Phe-amidegated channels (Lingueglia et al., 1995), nicotinic acetylcholine receptors (Ortells and Lunt, 1995), and ionotropic glutamate receptors (Hollmann and Heinemann, 1994). Previous studies have shown that, in peripheral neurons and in neuronal cell lines, coactivation of $\mathrm{P} 2 \mathrm{X}$ and nicotinic receptors elicits nonadditivity of ATP- and acetylcholine-induced currents (Nakazawa et al., 1991, 1994; Barajas-López et al., 1998; Searl et al., 1998; Zhou and Galligan, 1998; Khakh et al., 2001). A cross inhibition between the $\mathrm{P} 2 \mathrm{X}_{2}$ and the $\alpha_{3} \beta_{4}$ nicotinic receptor subtypes coexpressed in Xenopus oocytes has been reported previously (Khakh et al., 2000 ), and nonadditivity of P2X-and $\mathrm{GABA}_{\mathrm{A}}$-mediated currents

\footnotetext{
Received 0ct. 16, 2002; revised Nov. 25, 2002; accepted Nov. 26, 2002.

This work was supported by grants from the Canadian Institutes of Health Research, by the Heart and Stroke Foundation of Canada (P.S.), by Institut National de la Santé et de la Recherche Médicale (INSERM) (M.B.E.), by INSERM-Fonds de la Recherche en Santé du Quebec (E.B.-G., P.S.), and by postdoctoral awards from the Savoy Foundation for Epilepsy (E.B.-G., Y.C.). C.B.-L. is a Scholar of the Ontario Ministry of Health, and P.S. is a Scholar of the Fonds de la Recherche en Santé du Québec. We thank Audrey Speelman for expert technical assistance as well as John MacDonald (University of Toronto, Toronto, Canada) and Brian Mac Vicar (University of Calgary, Calgary, Canada) for their helpful comments during the preparation of this manuscript.

*E.B.-G. and C.B.-L. contributed equally to this work.

Correspondence should be addressed to Dr. Philippe Séguéla, Montreal Neurological Institute, 3801 University, Suite 778, Montreal, Quebec, Canada H3A 2B4. E-mail: philippe.seguela@mcgill.ca.

Copyright $\odot 2003$ Society for Neuroscience $\quad 0270-6474 / 03 / 231246-08 \$ 15.00 / 0$
}

has been observed in rat dorsal root ganglion neurons (Sokolova et al., 2001). Although these data indicate nonindependence of activity between $\mathrm{P} 2 \mathrm{X}$ and several members of the nicotinic receptor family, the mechanisms involved in this inhibitory cross talk remain to be elucidated.

5-Hydroxytryptamine (5-HT) receptor channels $\left(5-\mathrm{HT}_{3}\right)$ belong to the nicotinic acetylcholine receptor superfamily (Maricq et al., 1991; Davies et al., 1999) and mediate fast excitatory transmission in the nervous system (Derkach et al., 1989; Ugita et al., 1992; Barnes and Sharp, 1999). 5- $\mathrm{HT}_{3}$ and $\mathrm{P} 2 \mathrm{X}_{2}$ ATP receptors are coexpressed in several populations of central, sensory, sympathetic, and myenteric neurons (Tecott et al., 1993; BarajasLópez et al., 1996; Zhou and Galligan, 1996; Morales et al., 2001). Both neurotransmitter receptor subunits can assemble into functional homomeric channels, providing a unique molecular model to investigate whether specific interactions involving subunit domains may underlie functional coupling between excitatory receptor channels.

\section{Materials and Methods}

Receptor channels, minigenes, and glutathione S-transferase fusion proteins. The original wild-type rat $\mathrm{P}_{2} \mathrm{X}_{2}, 5-\mathrm{HT}_{3} \mathrm{~A}, 5-\mathrm{HT}_{3} \mathrm{~B}$, and $\rho 1$ clones were provided by D. Julius (University of California, San Francisco, CA), S. F. Heinemann (Salk Institute, La Jolla, CA), E. Kirkness (The Institute for Genomic Research, Rockville, MD), and M. Garret (University of Bordeaux, Bordeaux, France), respectively. The truncated $\mathrm{P} 2 \mathrm{X}_{2}$ (P2X $\mathrm{X}_{2} \mathrm{TR}$ ) construct was available from previous work (Boué-Grabot et al., 2000). The cDNAs coding for 5- $\mathrm{HT}_{3} \mathrm{~A}-\mathrm{Flag}$, enhanced green fluorescent protein (EGFP)-tagged $\mathrm{P}_{2} \mathrm{X}_{2}$, the main intracellular domain of $5-\mathrm{HT}_{3} \mathrm{~A}\left(5-\mathrm{HT}_{3} \mathrm{~A}-\mathrm{IL} 2\right)$, the C-terminal domain of $\mathrm{P} 2 \mathrm{X}_{2}\left(\mathrm{P} 2 \mathrm{X}_{2}-\mathrm{CT}\right)$, and the $\mathrm{N}$-terminal domain of $\mathrm{P} 2 \mathrm{X}_{2}\left(\mathrm{P}_{2} \mathrm{X}_{2}-\mathrm{NT}\right)$ were generated by PCR and 
subcloned into pcDNA3. P2X - -CT was also subcloned into pGEX2T (Amersham Biosciences, Arlington Heights, IL) to produce glutathione $S$-transferase (GST)-P2 $\mathrm{X}_{2}-\mathrm{CT}$ fusion protein in bacteria. All constructs were verified by DNA sequencing.

Electrophysiology in myenteric neurons. Whole-cell voltage-clamp recordings from cultured myenteric neurons of guinea pig proximal jejunum were performed as described previously (Barajas-López et al., 1996). Briefly, the neurons were dissociated using sequential enzymatic treatments with papain solution $(10 \mu \mathrm{l} / \mathrm{ml}$; activated with $0.4 \mathrm{mg} / \mathrm{ml}$ L-cysteine) followed by collagenase $(1 \mathrm{mg} / \mathrm{ml})$ and dispase $(4 \mathrm{mg} / \mathrm{ml})$. After washout, neurons were plated on coverslips coated with sterile rat tail collagen, placed in a recording chamber, and continuously superfused $(2 \mathrm{ml} / \mathrm{min})$ with an external solution containing (in $\mathrm{mm}$ ): 160 $\mathrm{NaCl}, 2 \mathrm{CaCl}_{2}, 11$ glucose, 5 HEPES, and $3 \mathrm{CsCl}, \mathrm{pH}$ 7.4. Whole-cell currents were made using glass pipettes filled with internal solution containing (in mM): 160 Cs-glutamate, 10 EGTA, 5 HEPES, $10 \mathrm{NaCl}, 3$ ATP-Mg, and 0.1 GTP, pH 7.3, and recorded via an Axopatch 1D amplifier (Axon Instruments, Foster City, CA) at a holding potential $\left(V_{\mathrm{H}}\right)$ of $-60 \mathrm{mV}$. For competition experiments, GST protein or GST-P2X $\mathrm{X}_{2}-\mathrm{CT}$ fusion protein $(75 \mu \mathrm{M})$ was included in the intracellular recording solution. Fast applications of 5-HT and ATP (Sigma, St. Louis, MO) were made using an eight barreled device. Because solutions were applied by gravity, we verified that the flow between different lines did not change significantly from the beginning to the end of the recording session. Results are reported as means \pm SEM; statistical differences were evaluated using Student's $t$ test.

Heterologous expression systems. Oocytes were prepared as described previously (Boué-Grabot et al., 2000). Stage V and VI oocytes were manually defolliculated before the microinjection of cRNAs. After injection (0.2 ng of RNA coding for $\mathrm{P}_{2} \mathrm{X}_{2}$ and 15-20 ng of RNA coding for $\mathrm{P} 2 \mathrm{X}_{2} \mathrm{TR}, 5-\mathrm{HT}_{3} \mathrm{~A}$, or nicotinic receptor subunits), oocytes were incubated with Barth's solution containing $1.8 \mathrm{mM} \mathrm{CaCl}_{2}$ at $19^{\circ} \mathrm{C}$ for $24-72$ $\mathrm{hr}$ before electrophysiological recordings. For competition experiments, RNAs corresponding to minigenes were injected (ranging between 20 and $60 \mathrm{ng}$ for each) independently in a second round of microinjection. Two-electrode voltage-clamp recordings were performed using glass pipettes (1-3 M $\Omega$ ) filled with $3 \mathrm{M} \mathrm{KCl}$ solution. Oocytes were placed in a recording chamber and were perfused at a flow rate of $10-12 \mathrm{ml} / \mathrm{min}$ with Ringer's solution containing (in $\mathrm{mm}$ ): $115 \mathrm{NaCl}, 5 \mathrm{NaOH}, 2.5 \mathrm{KCl}$, $1.8 \mathrm{CaCl}_{2}$ or $\mathrm{BaCl}_{2}$, and 10 HEPES, pH 7.4. Membrane currents (DC; 1 $\mathrm{kHz}$ ) were recorded through an $\mathrm{OC}-725 \mathrm{~B}$ amplifier (Warner Instruments, Hamden, CT) and digitized at $500 \mathrm{~Hz}$. All drugs (purchased from Sigma) were dissolved in the perfusion solution and applied using a computer-driven valve system. Because of the difference in time-to-peak between $5-\mathrm{HT}_{3}$ and $\mathrm{P} 2 \mathrm{X}_{2}$ currents recorded in oocytes (see Fig. $2 \mathrm{~A}$ ), we compared the peak of actual responses with the peak of predicted additive responses and not with the sum of the peaks of individual responses. All recordings were made at room temperature. Statistical differences between means were assessed using Student's $t$ test.

Whole-cell voltage clamps $\left(V_{\mathrm{H}}\right.$ of $-60 \mathrm{mV}$ ) from transfected human embryonic kidney (HEK) 293 cells were made using pipettes filled with internal solution containing (in $\mathrm{mM}$ ): $120 \mathrm{~K}$-gluconate, $1 \mathrm{MgCl}_{2}, 10$ HEPES, and $4 \mathrm{NaOH}, \mathrm{pH}$ 7.18. Cells were perfused $(2 \mathrm{ml} / \mathrm{min})$ with external solution $\left(22-24^{\circ} \mathrm{C}\right.$ ) containing (in $\mathrm{mM}$ ): $14 \mathrm{NaCl}, 3 \mathrm{KCl}, 1$ $\mathrm{MgCl}_{2}, 1 \mathrm{BaCl}_{2}, 10 \mathrm{HEPES}$, and $5 \mathrm{NaOH}, \mathrm{pH}$ 7.35. Currents (DC; $5 \mathrm{kHz}$ ) were recorded using an Axopatch-200B amplifier (Axon Instruments) and digitized at $500 \mathrm{~Hz}$. All values are reported as means \pm SEM, and differences were assessed using Student's $t$ test.

Immunoprecipitations and confocal imaging. Membrane proteins from HEK293 cells, transiently transfected with $\mathrm{P} 2 \mathrm{X}_{2}, \mathrm{P}_{2} \mathrm{X}_{2}-\mathrm{GFP}$, or $5-\mathrm{HT}_{3} \mathrm{~A}-$ Flag or cotransfected with $\mathrm{P} 2 \mathrm{X}_{2}-\mathrm{GFP}$ plus $5-\mathrm{HT}_{3} \mathrm{~A}-$ Flag or $\mathrm{P} 2 \mathrm{X}_{2}$ plus $5-\mathrm{HT}_{3} \mathrm{~A}-$ Flag using the calcium phosphate method, were homogenized in $10 \mathrm{~mm}$ HEPES and $0.3 \mathrm{~m}$ sucrose and solubilized in $1 \%$ Triton X-100 with protease inhibitors (Sigma) at $4^{\circ} \mathrm{C}$ before immunoaffinity purification on anti-Flag M2 resin (Sigma) as described previously (Boué-Grabot et al., 2000). In two experiments, HEK293 cells were incubated before homogenization in PBS buffer containing ATP plus 5-HT (100 $\mu$ M each). Bound proteins were eluted and then loaded onto a 10\% SDS-PAGE and transferred to a nitrocellulose membrane. Labeling of immunoprecipi-
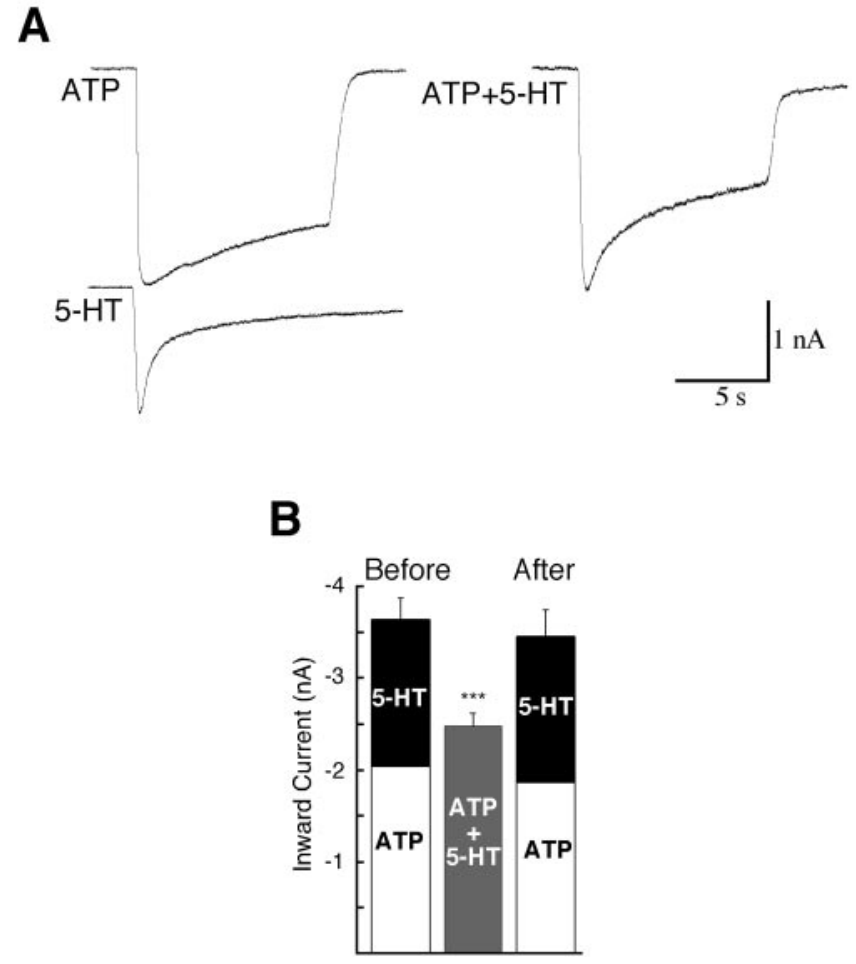

Figure 1. Inhibitory cross talk between ATP and 5-HT responses in guinea pig myenteric neurons. $A$, Representative whole-cell current responses induced by ATP, $5-\mathrm{HT}$, and ATP plus 5-HT (1 mm each). B, Mean values of ATP-and 5-HT-induced responses recorded $5 \mathrm{~min}$ before and $5 \mathrm{~min}$ after ATP plus 5 -HT responses from nine experiments. Whole-cell currents were measured at a $V_{H}$ of $-60 \mathrm{mV}$. ${ }^{* *} p<0.001$.

tated associated receptors was performed with anti-GFP antibodies (1: 5000; Molecular Probes, Eugene, OR), affinity-purified anti-P2X 2 antibodies (1:1000; Chemicon, Temecula, CA). or anti-Flag M2 antibodies (1:1000; Sigma) followed by incubation with corresponding peroxidaselabeled secondary antibodies (1:2000; Jackson ImmunoResearch, West Grove, PA) for visualization by enhanced chemiluminescence. In the experiments of competition, HEK293 cells were cotransfected with wildtype $\mathrm{P} 2 \mathrm{X}_{2}, 5-\mathrm{HT}_{3} \mathrm{~A}-\mathrm{Flag}$ subunits and $\mathrm{P} 2 \mathrm{X}_{2}-\mathrm{CT}$ or $\mathrm{P} 2 \mathrm{X}_{2}-\mathrm{NT}$ constructs at a cDNA ratio of 3:1 (minigene:subunits). Confocal fluorescence microscopy images were obtained from Chinese hamster ovary $(\mathrm{CHO})$ cells stably expressing $5-\mathrm{HT}_{3} \mathrm{~A}$ subunits after transient transfection with P2X $\mathrm{X}_{2}-\mathrm{GFP}$ and treatment with $5 \mu \mathrm{M}$ latrunculin-A for $18 \mathrm{hr}$. $5-\mathrm{HT}_{3}$ receptors were immunolocalized using anti-5- $\mathrm{HT}_{3} \mathrm{~A}$ antibodies (Doucet et al., 2000) and cyanine dye 3-conjugated secondary antibody; tagged $\mathrm{P} 2 \mathrm{X}_{2}$ receptors were visualized with GFP.

\section{Results}

Whole-cell voltage-clamp recordings were obtained from myenteric neurons acutely dissociated from guinea pig proximal jejunum. The application of saturating concentrations of ATP (1 $\mathrm{mM})$ evoked a slowly desensitizing inward current $\left(I_{\mathrm{ATP}}=\right.$ $-2.0 \pm 0.2 \mathrm{nA} ; n=9$ ), whereas an application of saturating concentrations of 5-HT ( $1 \mathrm{mM})$ induced a rapidly desensitizing current $\left(I_{5-\mathrm{HT}}=-1.61 \pm 0.1 \mathrm{nA}\right)$ (Fig. $\left.1 \mathrm{~A}\right)$. Interestingly, the coapplication of ATP and 5-HT (1 mM each) to the same neurons induced a large reversible inward current $\left(I_{\mathrm{ATP}}+I_{5-\mathrm{HT}}=\right.$ $-2.48 \pm 0.1 \mathrm{nA} ; n=9$ ) (Fig. 1) that was significantly smaller than the arithmetic sum of $I_{\mathrm{ATP}}$ and $I_{5-\mathrm{HT}}$ currents $(69 \pm 4 \%$ of predicted; $p<0.001)$. If responses to ATP and 5 -HT were attributable to the activation of functionally independent channels, the current induced by the simultaneous application of saturating concentrations of these transmitters, when the occupancy of both 
receptors reaches $100 \%$, should have been additive. The nonadditivity of currents induced by the concurrent activation of both native receptors indicates that ATP-gated and 5-HT-gated channels do not function independently in myenteric neurons. Nonadditivity was also recorded when subsaturating concentrations of ATP and 5-HT were used (data not shown).

Several neuronal P2X subtypes can generate slowly desensitizing currents; however, the distribution of $\mathrm{P}_{2} \mathrm{X}_{2}$ in guinea pig myenteric plexus (Castelluci al., 2002) and the loss of somatic $\mathrm{P} 2 \mathrm{X}$ currents in myenteric neurons of $\mathrm{P} 2 \mathrm{X}_{2}$ knock-out mice (Cockayne et al., 2002) suggest that these currents are mediated by homomeric $\mathrm{P}_{2} \mathrm{X}_{2}$ - or heteromeric $\mathrm{P} 2 \mathrm{X}_{2}$-containing ATP receptors. Therefore, the kinetic profiles of $I_{\mathrm{ATP}}$ and $I_{5-\mathrm{HT}}$ recorded in myenteric neurons (Fig. 1) are consistent with the activation of ionotropic $\mathrm{P}_{2} \mathrm{X}_{2}$ and $5-\mathrm{HT}_{3}$ receptor subtypes. Therefore, we expressed both receptor subunit cDNAs in Xenopus oocytes to test whether they also interact functionally in a heterologous system, to investigate the functional and molecular characteristics of the inhibitory cross talk between $\mathrm{P} 2 \mathrm{X}_{2}$ and $5-\mathrm{HT}_{3}$ channels. During two-electrode voltage-clamp recording in oocytes expressing both $\mathrm{P} 2 \mathrm{X}_{2}$ and $5-\mathrm{HT}_{3} \mathrm{~A}$ subunits, the simultaneous application of ATP and 5-HT (100 $\mu \mathrm{M}$ each) evoked an inward current $(-11.9 \pm 1.5 \mu \mathrm{A} ; n=22)$ that was significantly smaller $(p<$ $0.001)$ than the sum of responses to separate applications of 5-HT $\left(I_{5-\mathrm{HT}}=-2.7 \pm 0.5 \mu \mathrm{A}\right)$ and ATP $\left(I_{\mathrm{ATP}}=-14.5 \pm 1.8 \mu \mathrm{A}\right)($ Fig. $2 A$ ), demonstrating nonadditivity by occlusion. In agreement with our recordings in myenteric neurons, the amplitude of $I_{\mathrm{ATP}+5-\mathrm{HT}}$ represents $69 \pm 1 \%(n=28)$ of the predicted current corresponding to the arithmetic sum of $I_{\mathrm{ATP}}$ and $I_{5-\mathrm{HT}}$. Moreover, when 5-HT was applied during the continuous application of ATP, no modification or a rapid reduction in the amplitude of the $I_{\text {ATP }}$ was observed (Fig. $2 B$ ), revealing an instantaneous reciprocal current occlusion. The nonadditivity between $I_{5-\mathrm{HT}}$ and $I_{\mathrm{ATP}}$ was also recorded at submaximal concentrations of either agonist (Fig. $2 C$ ), by measuring outward currents at positive potentials (Fig. 2D), or in the absence of extracellular $\mathrm{Ca}^{2+}$ (data not shown). Coactivation of $\mathrm{P}_{2} \mathrm{X}_{2}$ and heteromeric $5-\mathrm{HT}_{3} \mathrm{~A}+\mathrm{B}$ receptors also produced current responses significantly smaller than the predicted current $(73 \pm 1 \% ; n=17)$ (Fig. $2 E$ ), suggesting that the $5-\mathrm{HT}_{3} \mathrm{~A}$ subunit is essential in the interaction between $5-\mathrm{HT}_{3}$ and $\mathrm{P} 2 \mathrm{X}$ receptors. Therefore, recombinant $\mathrm{P} 2 \mathrm{X}_{2}$ and $5-\mathrm{HT}_{3} \mathrm{~A}$ receptors do not function independently in Xenopus oocytes.

In oocytes expressing only $\mathrm{P} 2 \mathrm{X}_{2}$ receptors, the application of saturating concentrations of 5-HT did not activate $\mathrm{P}_{2} \mathrm{X}_{2}$ receptors, and the coapplication of ATP and 5-HT induced a current response identical in kinetics and in amplitude to $I_{\mathrm{ATP}}\left(I_{\mathrm{ATP}+5-\mathrm{HT}}\right.$ $=102 \pm 5 \%$ of $I_{\mathrm{ATP}} ; n=6$ ) (Fig. $3 A$ ). Similarly, ATP did not activate $5-\mathrm{HT}_{3} \mathrm{~A}$ channels, nor did it modulate $I_{5-\mathrm{HT}}\left(I_{\mathrm{ATP}+5-\mathrm{HT}}\right.$ $=102 \pm 2 \%$ of $\left.I_{5-\mathrm{HT}} ; n=6\right)$ (Fig. $\left.3 \mathrm{~B}\right)$ indicating that the crossinhibition between $5-\mathrm{HT}_{3} \mathrm{~A}$ and $\mathrm{P} 2 \mathrm{X}_{2}$ is not attributable to receptor cross-modulation.

In oocytes coexpressing $5-\mathrm{HT}_{3} \mathrm{~A}$ receptors and homomeric $\rho 1$ $\mathrm{GABA}_{\mathrm{C}}$ receptors, simultaneous applications of 5-HT $(100 \mu \mathrm{M})$ and GABA $(10 \mu \mathrm{M})$ evoked an inward current $(-2.66 \pm 0.58 \mu \mathrm{A}$; $n=12)$ that was not different from the sum of $I_{5-\mathrm{HT}}(-1.54 \pm$ $0.23 \mu \mathrm{A})$ and $I_{\mathrm{GABA}}(-1.18 \pm 0.4 \mu \mathrm{A})$ (Fig. $3 C$ ). $I_{5-\mathrm{HT}+\mathrm{GABA}}$ represented $97 \pm 4 \%$ of the predicted current (Fig. 3E). Additive currents were also recorded when 5-HT was applied during the prolonged application of GABA and vice versa (Fig. 3D). These results indicate that homomeric $5-\mathrm{HT}_{3} \mathrm{~A}$ receptors and $\rho 1$ $\mathrm{GABA}_{\mathrm{C}}$ receptors act as independent channels without cross talk in Xenopus oocytes.
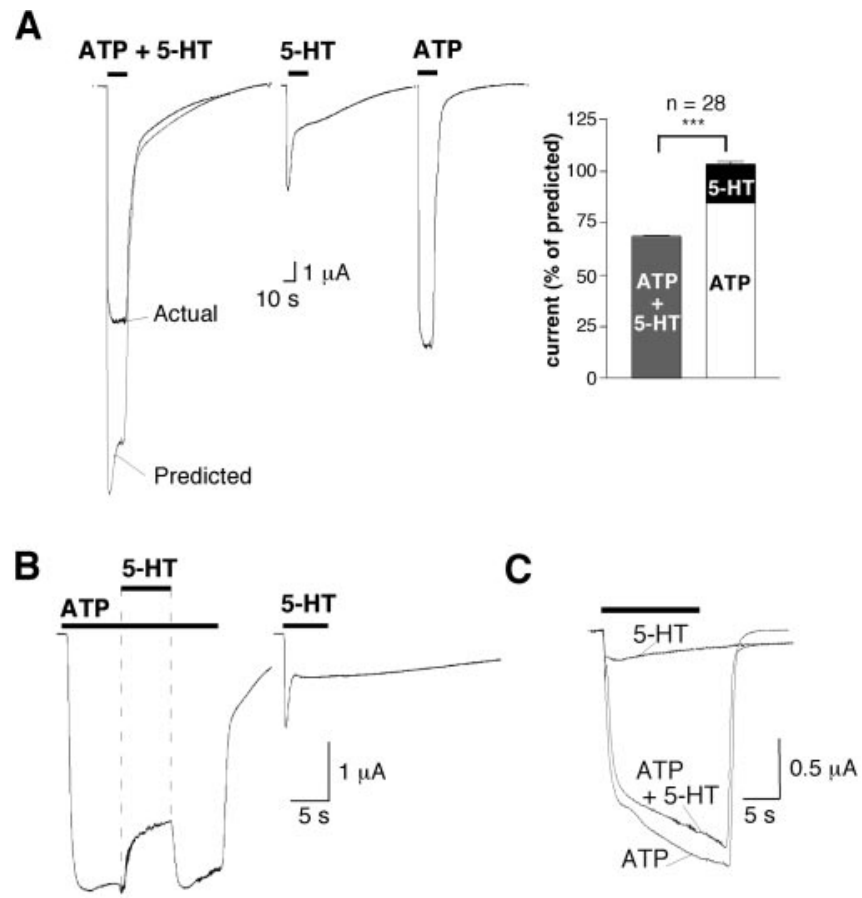

D
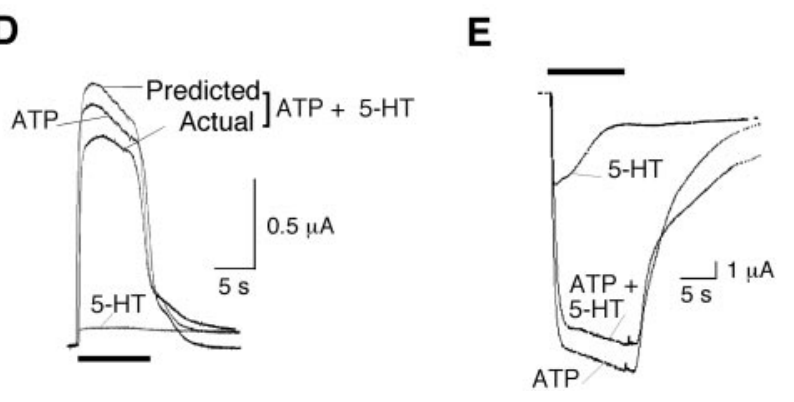

Figure 2. Cross-inhibition between recombinant $\mathrm{P}_{2} \mathrm{X}_{2}$ and $5-\mathrm{HT}_{3}$ receptor channels in Xenopus oocytes. A, B, Coapplication of ATP and 5-HT evoked inward currents (actual) significantly smaller than the arithmetic sum (predicted) of the individual ATP and $5-\mathrm{HT}$ responses. ${ }^{* * *} p<$ $0.001 ; n=28$. The amplitudes of the responses are normalized to the predicted response from each oocyte (bar graph). $V_{H}$ is $-60 \mathrm{mV}$. $B$, Current occlusion also occurs when 5 -HT application starts during ATP application. $C, D$, Superimposed traces obtained from Xenopus oocytes expressing $\mathrm{P}_{2} \mathrm{X}_{2}$ and $5-\mathrm{HT}_{3} \mathrm{~A}$ receptors activated with $1 \mu \mathrm{m}$ ATP, $100 \mu \mathrm{m} 5-\mathrm{HT}$, and both ATP and 5-HT ( $C$ and at $+40 \mathrm{mV} \mathrm{V} V_{\mathrm{H}}$ with a saturating concentration of agonists (100 $\mu \mathrm{m}$ each) (D). $E$, Nonadditivity of ATP and 5-HT responses is also observed in oocytes coexpressing $\mathrm{P}_{2} \mathrm{X}_{2}$ and heteromeric $5-\mathrm{HT}_{3} \mathrm{~A}+\mathrm{B}$ channels.

To determine whether intracellular domains could be involved in the functional interaction between $\mathrm{P} 2 \mathrm{X}_{2}$ and $5-\mathrm{HT}_{3} \mathrm{~A}$ receptors, we first truncated most of the cytoplasmic C-terminal domain of the $\mathrm{P} 2 \mathrm{X}_{2}$ receptor subunit by adding a stop codon at amino acid 365 ( $\left.\mathrm{P} 2 \mathrm{X}_{2} \mathrm{TR}\right)$. Truncated $\mathrm{P} 2 \mathrm{X}_{2}$ subunits have been shown previously to assemble into functional receptors (BouéGrabot et al., 2000). Contrary to the data obtained with wild-type $\mathrm{P} 2 \mathrm{X}_{2}$, coactivation of $\mathrm{P} 2 \mathrm{X}_{2} \mathrm{TR}$ and $5-\mathrm{HT}_{3} \mathrm{~A}$ receptors evoked a current response $(-3.4 \pm 0.8 \mu \mathrm{A} ; n=14)$ that was not significantly different $(p>0.5)$ from the sum of $I_{\mathrm{ATP}}$ and $I_{5-\mathrm{HT}}$ $(-0.72 \pm 0.24 \mu \mathrm{A}$ and $-2.07 \pm 0.42 \mu \mathrm{A}$, respectively; $n=14)$ (Fig. $4 A$ ). $I_{\mathrm{ATP}+5-\mathrm{HT}}$ represented $115 \pm 6 \%$ of the predicted current (Fig. $4 B$ ). The additivity of ATP and 5-HT responses was also observed when 5-HT applications started during the continuous application of ATP (Fig. 4C). The application of 5-HT to oocytes expressing $\mathrm{P} 2 \mathrm{X}_{2} \mathrm{TR}$ receptors alone did not activate or modulate $I_{\mathrm{ATP}}\left(I_{\mathrm{ATP}}+5\right.$-HT was $100 \pm 11 \%$ of $\left.I_{\mathrm{ATP}}\right)($ Fig. $4 D)$. Therefore, 
A

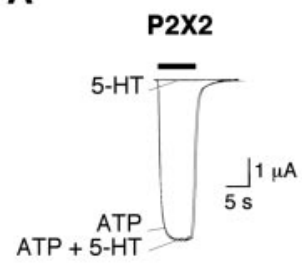

B

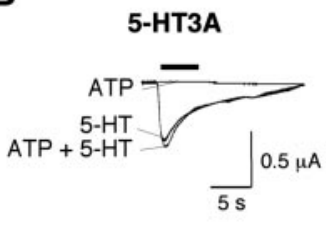

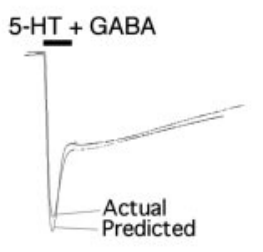

E

D

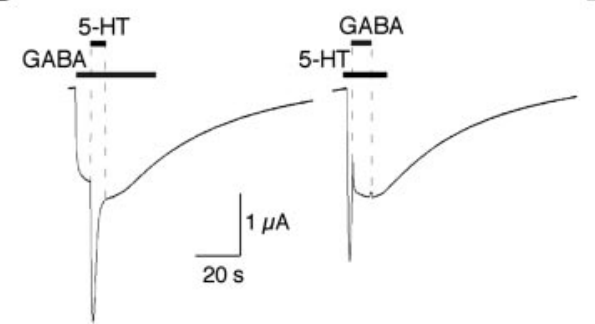

Figure 3. Cross talk between $\mathrm{P} 2 \mathrm{X}_{2}$ and $5-\mathrm{HT}_{3} \mathrm{~A}$ receptors is not attributable to crossmodulation and additivity of $5-\mathrm{HT}_{3}$ - and $\mathrm{GABA}_{C}$-mediated responses. Superimposed control traces obtained from Xenopus oocytes expressing ${\mathrm{P} 2 \mathrm{X}_{2}}_{2}(A)$ or $5-\mathrm{HT}_{3} \mathrm{~A}(B)$ receptors alone or with ATP, 5-HT, or a mixture of ATP and 5-HT (100 $\mu$ m each) are shown. C, Coexpression of homomeric $5-\mathrm{HT}_{3} \mathrm{~A}$ and $\rho 1 \mathrm{GABA}_{\mathrm{C}}$ receptors in Xenopus 00 cytes. Currents evoked by the application of $100 \mu \mathrm{m} 5$-HT and $10 \mu \mathrm{m} \mathrm{GABA}$ and by the coapplication of 5-HT plus GABA are shown. D, Additivity was also observed when GABA application started during 5-HT application and reciprocally. E, Inward currents evoked by the coapplication of GABA and 5-HT (actual) were not significantly different from the arithmetic sum (predicted) of the individual GABA and 5-HT currents $(n=12)$. ns, Not significant.

$\mathrm{P} 2 \mathrm{X}_{2} \mathrm{TR}$ and $5-\mathrm{HT}_{3} \mathrm{~A}$ receptors act as independent channels in Xenopus oocytes, suggesting an important role for the intracellular $\mathrm{P}_{2} \mathrm{X}_{2} \mathrm{C}$-terminal domain in the reciprocal cross-inhibition between wild-type $\mathrm{P} 2 \mathrm{X}_{2}$ and $5-\mathrm{HT}_{3} \mathrm{~A}$ activity. The functional interaction between $\mathrm{P} 2 \mathrm{X}_{2}$ and neuronal $\alpha_{3} \beta_{4}$ nicotinic channels $\left(I_{\mathrm{ATP}+\mathrm{ACh}}=80 \pm 2 \%\right.$ of predicted) (Fig. $\left.5 E\right)$ was also abolished when wild-type $\mathrm{P} 2 \mathrm{X}_{2}$ receptors were replaced with $\mathrm{P} 2 \mathrm{X}_{2} \mathrm{TR}$ receptors $\left(I_{\mathrm{ATP}+\text { Ach }}=93 \pm 4 \%\right.$ of predicted) (Fig. $\left.4 F\right)$, suggesting that the reciprocal inhibitory cross talk between $\mathrm{P} 2 \mathrm{X}$ receptors and nicotinic or $5-\mathrm{HT}_{3}$ receptors is based on similar intracellular mechanisms.

To generate competitive inhibitors of the functional interaction between $\mathrm{P} 2 \mathrm{X}_{2}$ and $5-\mathrm{HT}_{3}$ receptors, we designed two minigenes encoding soluble cytoplasmic forms of the C-terminal domain of $\mathrm{P} 2 \mathrm{X}_{2}$ receptors $\left(\mathrm{P} 2 \mathrm{X}_{2}-\mathrm{CT}\right.$, corresponding to amino acids $365-469)$ or of the $\mathrm{N}$-terminal domain of $\mathrm{P} 2 \mathrm{X}_{2}$ receptors $\left(\mathrm{P} 2 \mathrm{X}_{2}-\right.$ NT, corresponding to amino acids 1-29). As illustrated in Figure $5 A-C$, expression of $\mathrm{P}_{2} \mathrm{X}_{2}-\mathrm{CT}$ disrupted the interaction between $\mathrm{P} 2 \mathrm{X}_{2}$ and either $5-\mathrm{HT}_{3} \mathrm{~A}$ or $\alpha_{3} \beta_{4}$ nicotinic receptors, as demonstrated by the additive responses induced by the coapplication of ATP and either 5-HT or acetylcholine, without affecting the magnitude of the respective transmitter-evoked currents. This inhibition of the interaction by the $\mathrm{P} 2 \mathrm{X}_{2}-\mathrm{CT}$ minigene was concentration dependent (Fig. 5E). Nonadditive responses to coapplications of ATP and 5-HT were observed with the coex-

A
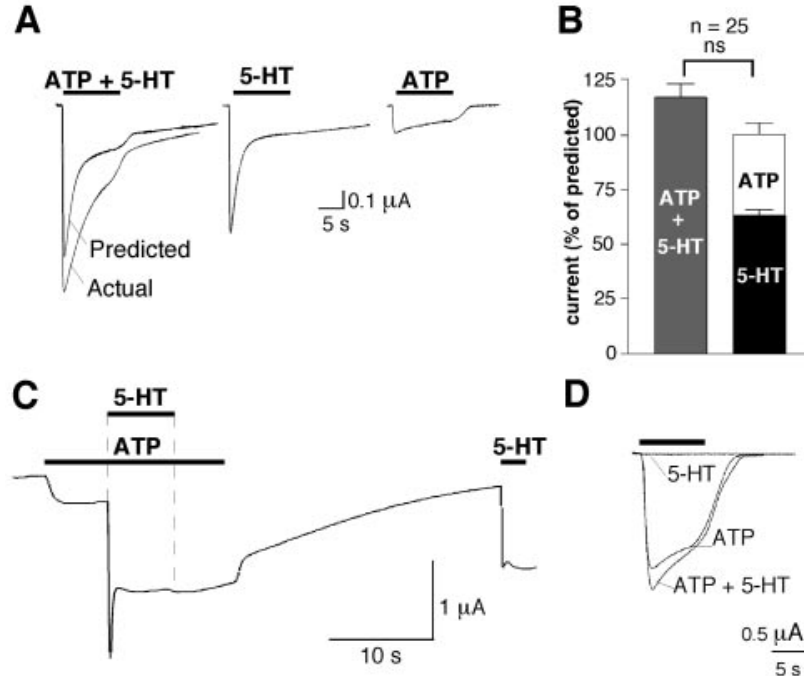

D

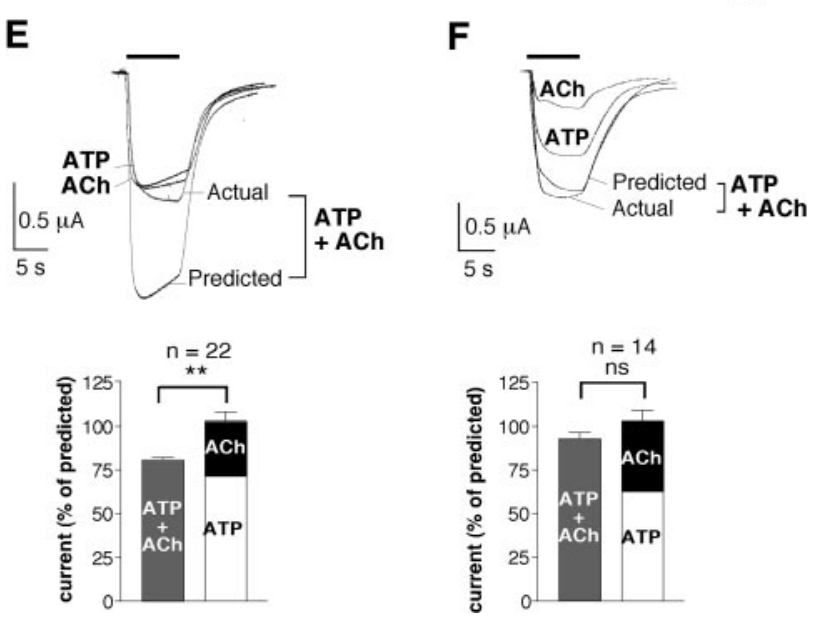

Figure 4. Additivity of agonist-induced responses in oocytes coexpressing $\mathrm{P} 2 \mathrm{X}_{2} \mathrm{TR}$ and either 5- $\mathrm{HT}_{3} \mathrm{~A}$ or $\alpha_{3} \beta_{4}$ nicotinic receptors. $A, C$, Representative current traces showing coexpression of $\mathrm{P} 2 \mathrm{X}_{2} \mathrm{TR}$ and $5-\mathrm{HT}_{3} \mathrm{~A}$ receptors in Xenopus 0ocytes. $B$, Mean current amplitudes showing the additivity of responses mediated by $\mathrm{P} 2 \mathrm{X}_{2} \mathrm{TR}$ and $5-\mathrm{HT}_{3} \mathrm{~A}$ channels. D, Representative superimposed currents with individual and combined applications of ATP and 5-HT (100 $\mu \mathrm{m})$ recorded from one oocyte expressing $P 2 X_{2}$ TR alone. $E$, Nonadditivity of $P 2 X_{2}$ and $\alpha_{3} \beta_{4}$ nicotinic currents in oocytes. ${ }^{* *} p<0.005 ; n=22$. F, In oocytes coexpressing P2X 2 TR and $\alpha_{3} \beta_{4}$ nicotinic channels, coapplications of ATP and ACh evoked inward currents (actual; $n=14$ ) that were not different from the sum of individual ATP and ACh responses (predicted). ns, Not significant.

pression of $\mathrm{P} 2 \mathrm{X}_{2}-\mathrm{NT}$, indicating that the $\mathrm{N}$-terminal domain of the $\mathrm{P} 2 \mathrm{X}_{2}$ subunit is not involved in the cross-inhibition between $\mathrm{P}_{2} \mathrm{X}_{2}$ and $5-\mathrm{HT}_{3} \mathrm{~A}$ receptors (Fig. 5B,E). Thus, the intracellular C-terminal domain of $\mathrm{P}_{2} \mathrm{X}_{2}$ receptors is determinant in their functional interaction with excitatory members of the nicotinic receptor gene superfamily.

To determine whether the cross talk between $\mathrm{P} 2 \mathrm{X}_{2}$ and $5-\mathrm{HT}_{3} \mathrm{~A}$ is also dependent on a cytoplasmic domain of $5-\mathrm{HT}_{3} \mathrm{~A}$ receptor subunit, we generated a minigene $\left(5-\mathrm{HT}_{3} \mathrm{~A}-\mathrm{IL} 2\right.$, corresponding to amino acids 316-418) encoding the large intracellular loop between the third and the fourth transmembrane domains. Coexpression of $5-\mathrm{HT}_{3} \mathrm{~A}-\mathrm{IL} 2$ with $\mathrm{P} 2 \mathrm{X}_{2}$ and $5-\mathrm{HT}_{3} \mathrm{~A}$ channels also disrupted the functional interaction (Fig. 5D) in a concentration-dependent manner (Fig. 5E).

A physical association between $\mathrm{P}_{2} \mathrm{X}_{2}$ and $5-\mathrm{HT}_{3} \mathrm{~A}$ receptor channels could underlie their functional interaction. Therefore, we performed affinity purification of Triton X-100-solubilized membrane protein extracts from HEK293 cells cotransfected 

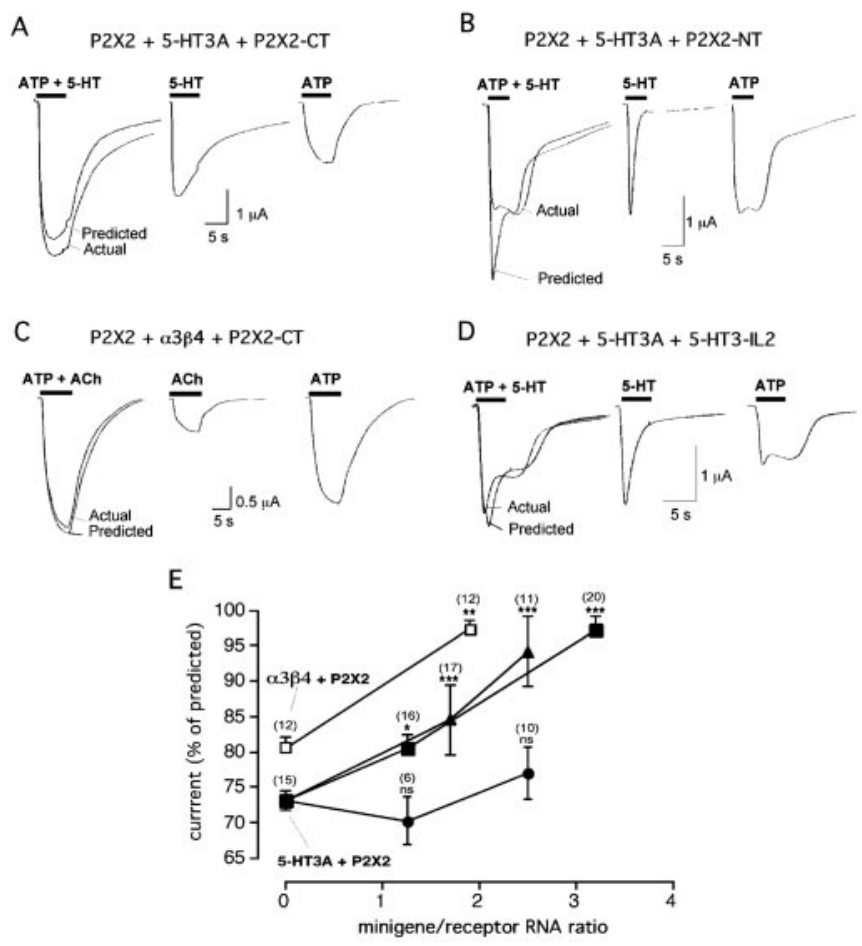

Figure 5. Cross talk between $\mathrm{P} 2 \mathrm{X}_{2}$ and $5-\mathrm{HT}_{3} \mathrm{~A}$ channels or between $\mathrm{P} 2 \mathrm{X}_{2}$ and $\alpha_{3} \beta_{4}$ nicotinic acetylcholine receptors is dependent on specific intracellular subunit domains. $A, B, D$, Inward currents evoked with $100 \mu \mathrm{M}$ ATP, with $100 \mu \mathrm{m} 5$-HT, or with both agonists (actual) in 0ocytes coexpressing $\mathrm{P} 2 \mathrm{X}_{2}$ and $5-\mathrm{HT}_{3} \mathrm{~A}$ channels. $A$, In the presence of a minigene encoding $\mathrm{P} 2 \mathrm{X}_{2}-\mathrm{CT}$. $B$, In the presence of a minigene encoding $P 2 X_{2}-N T$. $D$, In the presence of a minigene encoding 5-HT3-IL2. C, Currents induced with $100 \mu \mathrm{M}$ ATP, $100 \mu \mathrm{m}$ ACh, and both ATP and ACh (100 $\mu \mathrm{m}$ each) in oocytes coexpressing $\mathrm{P} 2 \mathrm{X}_{2}, \alpha_{3} \beta_{4}$ nicotinic channels, and $\mathrm{P} 2 \mathrm{X}_{2}-\mathrm{CT}$. E, Concentrationdependent inhibitory effect of P2X - CT $(\square, \square)$ or 5-HT3A-IL2 $(\boldsymbol{\Delta})$ on the functional interaction between $\mathrm{P} 2 \mathrm{X}_{2}$ and $5-\mathrm{HT}_{3} \mathrm{~A}$ and between $\mathrm{P} 2 \mathrm{X}_{2}$ and $\alpha_{3} \beta_{4}$ nicotinic channels. Numbers in parentheses indicate numbers of cells. ${ }^{*} p<0.05$. P2X $X_{2}-\mathrm{NT}(O)$ had no effect on the crossinhibition between $5-\mathrm{HT}_{3}$ and $\mathrm{P} 2 \mathrm{X}_{2}$ receptors $(p>0.5)$. Mean values of 5 -HT plus ATP responses normalized to the predicted response without minigene and with increasing amounts of minigenes are shown. ${ }^{* *} p<0.005 ;{ }^{* * *} p<0.0005$. ns, Not significant.

with functionally interacting GFP-tagged $\mathrm{P}_{2} \mathrm{X}_{2}$ and Flag-tagged $5-\mathrm{HT}_{3} \mathrm{~A}$ receptors to test this hypothesis. The coapplication of ATP and 5-HT $(100 \mu \mathrm{M})$ evoked an inward current $(-2.2 \pm 0.5$ $\mathrm{nA} ; n=5$ ) that was significantly smaller than the sum of $I_{\mathrm{ATP}}$ and $I_{5-\mathrm{HT}}(-4.7 \pm 0.8 \mathrm{nA})$ in transfected HEK293 cells (actual $I_{5-\mathrm{HT}+\mathrm{ATP}}=47 \pm 7 \%$ of predicted response) (Fig. $6 \mathrm{~A}, \mathrm{E}$ ). After immunopurification on anti-Flag resin, a band of $95 \mathrm{kDa}$ relative molecular mass corresponding to the expected size of the $\mathrm{P} 2 \mathrm{X}_{2}-$ GFP subunit was revealed with anti-GFP antibodies, demonstrating a physical association between $\mathrm{P} 2 \mathrm{X}_{2}$ and $5-\mathrm{HT}_{3}$ receptors (Fig. $6 B$ ). The specificity of the coimmunoprecipitation was verified by the absence of the signal detected with purified proteins from HEK293 cells transfected with $\mathrm{P}_{2} \mathrm{X}_{2}-\mathrm{GFP}$ alone, with membrane proteins from nontransfected cells (Fig. $6 B$ ), or after mixing membrane proteins from two batches of HEK293 cells expressing either $\mathrm{P}_{2} \mathrm{X}_{2}$ or $5-\mathrm{HT}_{3}$ receptors (data not shown). A physical association between the two receptors was observed with or without activation of the receptors by a $100 \mu \mathrm{M}$ concentration of their respective agonists ATP and 5-HT (Fig. 6B). Coexpression of $\mathrm{P}_{2} \mathrm{X}_{2}$ and $5-\mathrm{HT}_{3}-$ Flag receptors with minigenes encoding $\mathrm{P}_{2} \mathrm{X}_{2} \mathrm{~N}$ - or C-terminal domains did not inhibit their physical interaction, as shown by the detection of $\mathrm{P}_{2} \mathrm{X}_{2}$ after immunopurification on anti-Flag resin (Fig. 6D). Overexpression of the $\mathrm{P}_{2} \mathrm{X}_{2}-\mathrm{CT}$ minigene was checked by recording the loss of func- tional interaction between $\mathrm{P} 2 \mathrm{X}_{2}$ and $5-\mathrm{HT}_{3}$ receptors in patch clamp. Coapplication of ATP and 5-HT (100 $\mu \mathrm{M})$ evoked an inward current $(-3.2 \pm 0.5 \mathrm{nA} ; n=3)$ that was not significantly different from the sum of $I_{\mathrm{ATP}}$ and $I_{5-\mathrm{HT}}(-2.7 \pm 0.3 \mathrm{nA})$ in transfected HEK 293 cells (actual $I_{5-\mathrm{HT}+\mathrm{ATP}}=84 \pm 6 \%$ of predicted response) (Fig. 6C). These results indicate the existence of constitutive $\mathrm{P}_{2} \mathrm{X}_{2}$ plus $5-\mathrm{HT}_{3} \mathrm{~A}$ complexes in the plasma membrane and suggest that if intracellular domains are necessary for the functional cross-inhibition, other domains of $\mathrm{P} 2 \mathrm{X}_{2}$ and $5-\mathrm{HT}_{3}$ receptors are possibly involved in the physical association. Indeed, multireceptor clusters containing GFP-tagged $\mathrm{P}_{2} \mathrm{X}_{2}$ and $5-\mathrm{HT}_{3} \mathrm{~A}$ receptors were localized at the surface of transfected cells using confocal fluorescence microscopy (Fig. $6 F$ ).

Because the cross talk between recombinant $\mathrm{P}_{2} \mathrm{X}_{2}$ and 5 - $\mathrm{HT}_{3} \mathrm{~A}$ receptors was disrupted by the expression of minigenes encoding specific intracellular receptor subunit domains, we then tested whether the cross talk between native $\mathrm{P} 2 \mathrm{X}_{2}$ and $5-\mathrm{HT}_{3}$ receptors could also be disrupted in neurons using a similar strategy of competition. Indeed, we observed that the intracellular infusion of GST-P2X $\mathrm{X}_{2}-\mathrm{CT}$ fusion protein through the recording pipette into the cytoplasm of myenteric neurons significantly reduced the functional interaction $\left(I_{5-\mathrm{HT}+\mathrm{ATP}}=86 \pm 3 \%\right.$ of the predicted; $p<0.005 ; n=8$ ) (Fig. $7 A-C$ ) recorded in neurons infused with buffer alone $\left(I_{5-\mathrm{HT}+\mathrm{ATP}}=72 \pm 2 \%\right.$ of predicted; $n=$ 8) (Fig. $7 C)$ or GST alone $\left(I_{5-\mathrm{HT}+\mathrm{ATP}}=73 \pm 5 \%\right.$ of predicted; $n=$ 6) (Fig. $7 B, C$ ). Responses to 5 -HT and ATP were not additive at the time at which the whole-cell configuration was established but became additive 30 min later in the same neuron, after dialysis of the cytoplasm with the fusion protein GST-P2X $\mathrm{X}_{2}-\mathrm{CT}$ (Fig. $7 D$ ). Therefore, the inhibitory cross talk between native and recombinant $5-\mathrm{HT}_{3}$ and $\mathrm{P} 2 \mathrm{X}_{2}$ receptor channels is mediated by the activity-dependent coupling of specific intracellular subunit domains.

\section{Discussion}

Here we present the first evidence that two structurally unrelated ligand-gated channels, $\mathrm{P} 2 \mathrm{X}_{2}$ and $5-\mathrm{HT}_{3}$ receptors, are physically associated, and that specific intracellular domains are necessary for the expression of their cross-inhibition. Coactivation of both receptor channels expressed natively in myenteric neurons or in recombinant heterologous systems triggers an instantaneous reciprocal current occlusion in a situation similar to the crossinhibition between $\mathrm{P} 2 \mathrm{X}_{2}$ and $\alpha_{3} \beta_{4}$ nicotinic receptors reported previously (Barajas-López et al., 1996; Zhou and Galligan, 1996; Khakh et al., 2000). This receptor-mediated cross talk between $\mathrm{P}_{2} \mathrm{X}_{2}$ and $5-\mathrm{HT}_{3}$ responses is calcium, voltage, and agonist concentration independent. It is not attributable to crossmodulation, because ATP has no effect on $5-\mathrm{HT}_{3}$ receptors and 5-HT does not activate $\mathrm{P}_{2} \mathrm{X}_{2}$ receptors, and the cross talk shows some receptor specificity, because $5-\mathrm{HT}_{3}$ receptors do not interact with $\mathrm{GABA}_{\mathrm{C}}$ receptors.

The functional independence observed between truncated $\mathrm{P} 2 \mathrm{X}_{2}$ and $5-\mathrm{HT}_{3} \mathrm{~A}$ receptors as well as the suppression of the cross talk between wild-type $\mathrm{P} 2 \mathrm{X}_{2}$ and $5-\mathrm{HT}_{3}$ receptors in competition experiments with the intracellular loop of $5-\mathrm{HT}_{3} \mathrm{~A}$ subunit and with the $\mathrm{C}$-terminal (but not the $\mathrm{N}$-terminal) domain of $\mathrm{P} 2 \mathrm{X}_{2}$ demonstrate the involvement of cytoplasmic sequences from both receptor subunits in the functional interaction in native neurons and in heterologous expression systems. These results, in line with the absence of cross-modulation, eliminate the possibility of a major role for second messengers generated by endogenous and electrophysiologically silent metabotropic P2Y or 5-HT receptors in this inhibitory cross talk. The involvement of the 
A

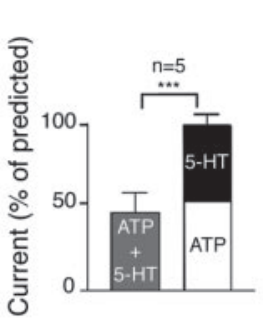

C

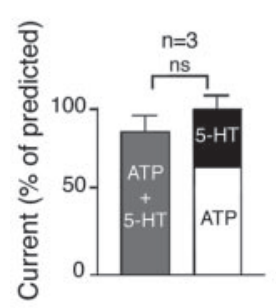

E

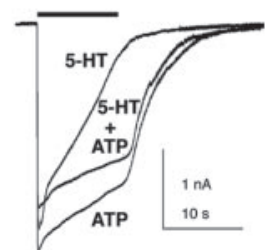

B
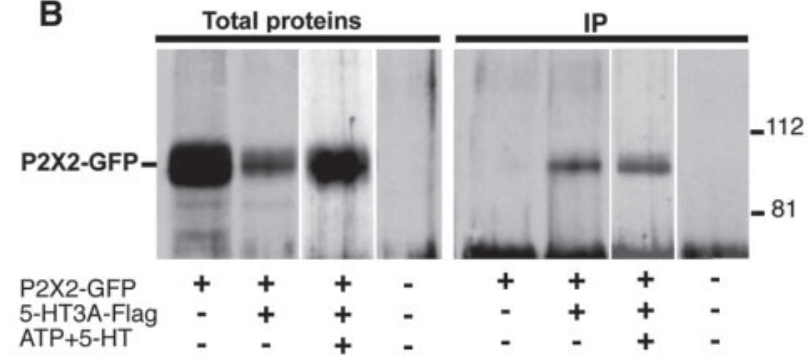

D

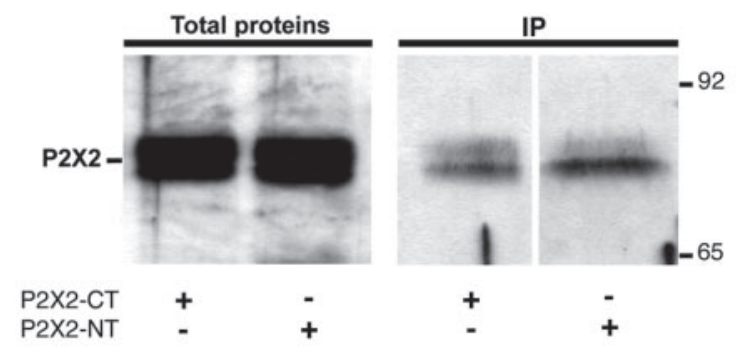

$\mathbf{F}$
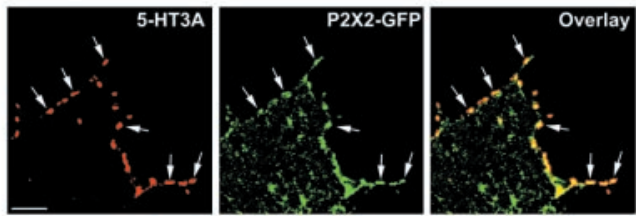

Figure 6. Constitutive physical association and coclustering of $\mathrm{P} 2 \mathrm{X}_{2}$ and $5-\mathrm{HT}_{3} \mathrm{~A}$ receptor channels. $A, E$, Nonadditive current responses from HEK293 cells transfected with $\mathrm{P} 2 \mathrm{X}_{2}-\mathrm{GFP}$ and $5-\mathrm{HT}_{3} \mathrm{~A}-$ Flag to separate applications of $100 \mu \mathrm{M}$ ATP,

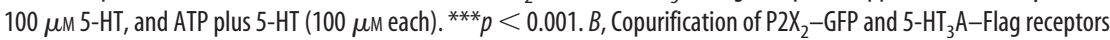
from transfected HEK293 cells. Transfected HEK293 cells were incubated in the presence $(+)$ or absence $(-)$ of the agonists ATP and 5-HT (100 $\mu$ m each) before homogenization. IP, Immunoprecipitation. C, Additivity of the $\mathrm{P}_{2} \mathrm{X}_{2}$ and $5-\mathrm{HT}_{3}$ responses in HEK293 cells cotransfected with wild-type $\mathrm{P} 2 \mathrm{X}_{2}, 5-\mathrm{HT}_{3} \mathrm{~A}-\mathrm{Flag}$, and $\mathrm{P} 2 \mathrm{X}_{2}-\mathrm{CT}$ minigene. $n$ s, Not significant. D, $\mathrm{P} 2 \mathrm{X}_{2}$ and $5-\mathrm{HT}_{3}$ receptors were coimmunopurified when coexpressed with the $\mathrm{P} 2 \mathrm{X}_{2}-\mathrm{CT}$ or $\mathrm{P} 2 \mathrm{X}_{2}-\mathrm{NT}$ minigene. The Western blots are representative of 10 independent experiments; numbers indicate molecular mass markers in kilodaltons. $F$, Confocal microscopy images showing membrane colocalization of $5-\mathrm{HT}_{3} \mathrm{~A}$ and $\mathrm{P} 2 \mathrm{X}_{2}-\mathrm{GFP}$ receptors in transfected $\mathrm{CHO}$ cells. Arrows in the overlay panel indicate coclusters of the two types of neurotransmitter-gated channels. Scale bar, $10 \mu \mathrm{m}$.

intracellular C-terminal domain of $\mathrm{P}_{2} \mathrm{X}_{2}$ in the cross talk with $\alpha_{3} \beta_{4}$ nicotinic acetylcholine-gated channels demonstrated here strongly suggests that a generic molecular mechanism underlies the functional coupling observed between P2X ATP receptors and members of the nicotinic receptor superfamily. Although the inhibitory cross talk between $\mathrm{GABA}_{\mathrm{A}}$ and $\mathrm{P} 2 \mathrm{X}$ receptors appears to be chloride and calcium dependent in dorsal root ganglion sensory neurons (Sokolova et al., 2001), the possibility of intracellular interactions between $\mathrm{GABA}_{\mathrm{A}}$ and P2X subunits should now be investigated.

Specific associations linking metabotropic G-protein-coupled receptors and ion channels have been shown to mediate, for example, the inhibition of neurotransmitter-gated channels by dopamine receptors (Liu et al., 2000; Lee et al., 2002) and the increase in L-type voltage-gated calcium channel activity by the stimulation of $\beta_{2}$ adrenergic receptors (Davare et al., 2001). It is clear now that P2X channels interact with several members of the nicotinic receptor superfamily, and conversely, nicotinic and GABA receptors interact with several ATP-gated channel sub- types (Khakh et al., 2000; Sokolova et al., 2001). The fact that the C-terminal sequences in the P2X family or the intracellular domains of the nicotinic receptor family members display no clear homology at the level of their primary sequence argues in favor of a coupling between channel motifs with conserved tertiary structures. Moreover, the lack of a modulatory effect of overexpressed cytoplasmic domains on the function of the other receptor partners (at least for current amplitudes and kinetics) in our competition experiments suggests an activity-dependent coupling. Interestingly, overexpression of a minigene encoding the C-terminal domain of $\mathrm{P}_{2} \mathrm{X}_{2}$ in transfected cells has a clear competitive disrupting effect on the functional interaction between $\mathrm{P} 2 \mathrm{X}_{2}$ and $5-\mathrm{HT}_{3}$ receptors but did not prevent their coimmunoprecipitation. Although we cannot exclude the allosteric participation of extracellular or transmembrane regions of $\mathrm{P}_{2} \mathrm{X}_{2}$ and $5-\mathrm{HT}_{3}$ subunits to the cross talk, our results strongly support the existence of two distinct types of interaction between the receptor channels: an activity-dependent intracellular coupling and a constitutive physical association involving other determinants that remain to be identified.

Functional cross talks between P2X ATPgated channels and $5-\mathrm{HT}_{3} \mathrm{~A}$ or nicotinic receptors were recorded in Xenopus oocytes and in mammalian cell lines as well as in several neuronal types. This widespread occurrence suggests that, if indirect, receptor-receptor functional couplings might depend on the expression of ubiquitous and conserved intracellular partners.

The large cytoplasmic domain of channel subunits belonging to the nicotinic receptor superfamily is necessary for the functional coupling with $\mathrm{P} 2 \mathrm{X}$ receptors, but it is also required for targeting and/or postsynaptic clustering through specific interactions with receptor-associated proteins. For example, muscle nicotinic acetylcholine receptors associate with rapsyn (Maimone and Enigk, 1999) and glycine, $\mathrm{GABA}_{\mathrm{A}}$ receptors associate with gephyrin (Meyer et al., 1995; Essrich et al., 1998), and specific GABA receptor subunits associate with GABA receptor-associated protein or MAP-1B (Hanley et al., 1999; Wang et al., 1999). Although proteins associated with $5-\mathrm{HT}_{3}$ receptors and neuronal $\mathrm{P} 2 \mathrm{X}$ receptors are not yet known, direct or indirect constitutive interactions of $\mathrm{P} 2 \mathrm{X}$ receptors with $5-\mathrm{HT}_{3}$ receptors might also play a role in targeting both of them to specific synaptic or extrasynaptic localizations in coclusters at the neuronal surface (Rubio and Soto, 2001).

In vivo, several transmitters can be coreleased in the synaptic cleft (Docherty et al., 1987; Jonas et al., 1998), and ATP is known to be a cotransmitter in a variety of neuroneuronal and neuroeffector synapses (Burnstock, 1986; Jo and Schlichter, 1999; Poelchen et al., 2001). In the guinea pig myenteric nervous system, the high density of serotonergic varicose nerve fibers originates primarily from intrinsic neurons (Furness and Costa, 1982; 
A
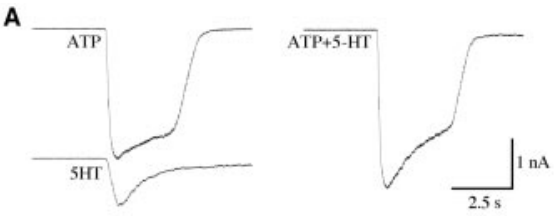

B
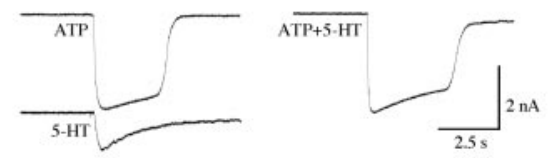

D

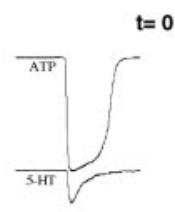

$\mathrm{t}=\mathbf{0}$
C

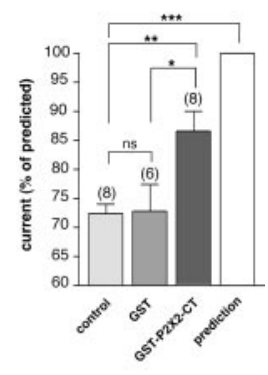

myenteric intrinsic primary afferent neurons of the guinea-pig ileum are excited by 5 -hydroxytryptamine acting at 5-hydroxytryptamine- 3 receptors. Neuroscience 101:459-469.

Boué-Grabot E, Archambault V, Séguéla P (2000) A protein kinase C site highly conserved in $\mathrm{P} 2 \mathrm{X}$ subunits controls the desensitization kinetics of P2X2 ATP-gated channels. J Biol Chem 275:10190-10195.

Bueno L, Fioramonti J (1999) Effects of inflammatory mediators on gut sensitivity. Can J Gastroenterol 13:42A-46A.

Burnstock G (1986) Purines and cotransmitters in adrenergic and cholinergic neurones. Prog Brain Res 68:193-203.

Castelucci P, Robbins HL, Poole DP, Furness JB (2002) The distribution of purine $\mathrm{P} 2 \mathrm{X}_{2}$ receptors in the guinea-pig enteric nervous system. Histochem Cell Biol 117:415-422.

Cockayne DA, Dunn PM, Burnstock G, Ford APD (2002) Generation and electrophysiological characterization of $\mathrm{P} 2 \mathrm{X}_{2}$ and $\mathrm{P} 2 \mathrm{X}_{2 / 3}$ knockout mice. Soc Neurosci Abstr 28:12.

Davare MA, Avdonin V, Hall DD, Peden EM, Burette A, Weinberg RJ, Horne MC, Hoshi T, Hell JW (2001) A $\beta 2$ adrenergic receptor signaling complex assembled with the $\mathrm{Ca}^{2+}$ channel Cav1.2. Science 293:98-101.

Davies PA, Pistis M, Hanna MC, Peters JA, Lambert JJ, Hales TG, Kirkness EF (1999) The 5-HT3B subunit is a major determinant of serotoninreceptor function. Nature 397:359-363.

Figure 7. Disruption of cross talk between $\mathrm{P}_{2} \mathrm{X}_{2}$ and $5-\mathrm{HT}_{3}$ receptors in myenteric neurons by intracellular GST-P2X 2 -CT fusion protein. $A$, Representative additive whole-cell current responses induced by ATP, 5-HT, and ATP plus 5-HT (1 mm each) recorded $30 \mathrm{~min}$ after the infusion of GST-P2X 2 -CT fusion protein. $B$, Control inhibitory cross talk after infusion with GST alone in the recording pipette. C, Mean values of 5 -HT plus ATP responses normalized to the predicted response with buffer only (control) and with fusion proteins (GST or GST-P2X - CT). ${ }^{*} p<0.05$; ${ }^{* *} p<0.005 ;{ }^{* * *} p<0.0005$. ns, Not significant. D, Current traces obtained from one typical neuron before $(t=0)$ and after the infusion of GST-P2X - CT fusion protein ( $t=30 \mathrm{~min})$. Whole-cell currents were measured at a $V_{\mathrm{H}}$ of $-60 \mathrm{mV}$.

Wardell et al., 1994). Enterochromaffin cells (Racké et al., 1996), platelets, and mast cells (Bueno and Fioramonti, 1999) provide non-neuronal sources of ATP and 5-HT. Both excitatory mediators have the ability to depolarize the mucosal nerve terminals (Bertrand et al., 2000, 2002). The interactions between P2X and $5-\mathrm{HT}_{3}$ receptors coexpressed in the terminals of myenteric sensory neurons (Bertrand et al., 2002) could thus play a regulatory role by buffering the paracrine effects of ATP and 5-HT on reflex actions.

The functional cross-inhibition between ATP-gated channels and other excitatory transmitter-gated channels of the nicotinic receptor family may regulate neuronal excitability and synaptic plasticity by limiting both the level of depolarization and the flow of calcium ions through calcium-permeable $\mathrm{P} 2 \mathrm{X}$ receptors (Koshimizu et al., 2000). Alternatively, in pathological conditions of neuronal hyperactivity, it may also play a protective role by preventing overexcitation and calcium-dependent excitotoxicity.

Thus, the existence of intracellular interactions in multireceptor complexes linking the activity of different types of receptor channels reveals a novel mode of fast signal processing and coincidence detection at the membrane level whose extent in the nervous system and other excitable tissues remains to be explored.

\section{References}

Barajas-López C, Huizinga JD, Collins SM, Gerzanich V, Espinosa-Luna R, Peres AL (1996) P2X-purinoceptors of myenteric neurones from the guinea-pig ileum and their unusual pharmacological properties. $\mathrm{Br} \mathrm{J}$ Pharmacol 19:1541-1548.

Barajas-López C, Espinosa-Luna R, Zhu Y (1998) Functional interactions between nicotinic and P2X channels in short-term cultures of guinea-pig submucosal neurons. J Physiol (Lond) 513:671-683.

Barnes NM, Sharp T (1999) A review of central 5-HT receptors and their function. Neuropharmacology 38:1083-1152.

Bertrand PP, Bornstein JC (2002) ATP as a putative sensory mediator: activation of intrinsic sensory neurons of the myenteric plexus via $\mathrm{P} 2 \mathrm{X}$ receptors. J Neurosci 22:4767-4775.

Bertrand PP, Kunze WAA, Furness JB, Bornstein JC (2000) The terminals of

Derkach V, Surprenant A, North RA (1989) 5-HT3 receptors are membrane ion channels. Nature 339:706-709.

Docherty M, Bradford HF, Wu JY (1987) Co-release of glutamate and aspartate from cholinergic and GABAergic synaptosomes. Nature 330:64-66.

Doucet E, Miquel MC, Nosjean A, Verge D, Hamon M, Emerit MB (2000) Immunolabeling of the rat central nervous system with antibodies partially selective of the short form of the 5-HT3 receptor. Neuroscience 95:881-892.

Essrich C, Lorez M, Benson JA, Fritschy JM, Luscher B (1998) Postsynaptic clustering of major $\mathrm{GABA}_{\mathrm{A}}$ receptor subtypes requires the $\gamma 2$ subunit and gephyrin. Nat Neurosci 1:563-572.

Furness JB, Costa M (1982) Neurons with 5-hydroxytryptamine-like immunoreactivity in the enteric nervous system: their projections in the guinea-pig small intestine. Neuroscience 7:341-349.

Hanley JG, Koulen P, Bedford F, Gordon-Weeks PR, Moss SJ (1999) The protein MAP-1B links GABAc receptors to the cytoskeleton at retinal synapses. Nature 397:66-69.

Hollmann M, Heinemann S (1994) Cloned glutamate receptors. Annu Rev Neurosci 17:31-108.

Jo YH, Schlichter R (1999) Synaptic corelease of ATP and GABA in cultured spinal neurons. Nat Neurosci 2:241-245.

Jonas P, Bischofberger J, Sandkuhler J (1998) Corelease of two fast neurotransmitters at a central synapse. Science 281:419-424.

Khakh B, Zhou X, Sydes J, Galligan JJ, Lester HA (2000) State-dependent cross-inhibition between transmitter-gated cation channels. Nature 406:405-410.

Khakh B, Burnstock G, Kennedy C, King BF, North RA, Séguéla P, Voigt M, Humphrey PPA (2001) Current status of the nomenclature and properties of P2X receptors and their subunits. Pharmacol Rev 5:107-118.

Koshimizu TA, Van Goor F, Tomic M, Wong AOL, Tanoue A, Tsujimoto G, Stojilkovic S (2000) Characterization of calcium signaling by purinergic receptor-channels expressed in excitable cells. Mol Pharmacol 58:936-945.

Lee FJ, Xue S, Pei L, Vukusic B, Chery N, Wang Y, Wang YT, Niznik HB, Yu X, Liu F (2002) Dual regulation of NMDA receptor functions by direct protein-protein interactions with the dopamine D1 receptor. Cell 111:219-230.

Lingueglia E, Champigny G, Lazdunski M, Barbry P (1995) Cloning of the amiloride-sensitive FMRFamide peptide-gated sodium channel. Nature 378:730-733.

Liu F, Wan Q, Pristupa ZB, Yu XM, Niznik HB (2000) Direct proteinprotein coupling enables cross-talk between dopamine D5 and $\gamma$-aminobutyric acid A receptors. Nature 403:274-280.

Maimone MM, Enigk RE (1999) The intracellular domain of the nicotinic acetylcholine receptor $\alpha$ subunit mediates its coclustering with rapsyn. Mol Cell Neurosci 14:340-354.

Maricq AV, Peterson AS, Brake AJ, Myers RM, Julius D (1991) Primary structure and functional expression of the 5 HT3 receptor, a serotoningated ion channel. Science 254:432-437. 
Meyer G, Kirsch J, Betz H, Langosch D (1995) Identification of a gephyrin binding motif on the glycine receptor $\beta$ subunit. Neuron 15:563-572.

Morales M, McCollum N, Kirkness EF (2001) 5-HT3-receptor subunits A and $\mathrm{B}$ are coexpressed in neurons of the dorsal root ganglion. J Comp Neurol 438:163-172.

Nakazawa K (1994) ATP-activated current and its interaction with acetylcholine-activated current in rat sympathetic neurons. J Neurosci 14:740-750.

Nakazawa K, Fujimori K, Takanaka A, Inoue K (1991) Comparison of adenosine triphosphate- and nicotine-activated inward currents in rat phaeochromocytoma cells. J Physiol (Lond) 434:647-656.

Ortells MO, Lunt GG (1995) Evolutionary history of the ligand-gated ionchannel superfamily of receptors. Trends Neurosci 18:121-127.

Poelchen W, Sieler D, Wirkner K, Ille P (2001) Co-transmitter function of ATP in central catecholaminergic neurons of the rat. Neuroscience 102:593-602.

Rubio ME, Soto F (2001) Distinct localization of P2X receptors at excitatory postsynaptic specializations. J Neurosci 15:641-653.

Sakmann B (1992) Elementary steps in synaptic transmission revealed by currents through single ion channels. Neuron 8:613-629.

Searl TJ, Redman RS, Silinski EM (1998) Mutual occlusion of P2X ATP receptors and nicotinic receptors on sympathetic neurons of the guineapig. J Physiol (Lond) 510:783-791.

Sokolova E, Nistri A, Giniatullin R (2001) Negative cross talk between anionic $\mathrm{GABA}_{\mathrm{A}}$ and cationic $\mathrm{P} 2 \mathrm{X}$ ionotropic receptors of rat dorsal root ganglion neurons. J Neurosci 21:4958-4968.

Tecott LH, Maricq AV, Julius D (1993) Nervous system distribution of the serotonin 5-HT3 receptor mRNA. Proc Natl Acad Sci USA 90:1430-1434.

Ugita S, Shen KZ, North RA (1992) 5-hydroxytryptamine is a fast excitatory transmitter at 5-HT3 receptors in rat amygdala. Neuron 8:199-203.

Wang H, Bedford FK, Brandon NJ, Moss SJ, Olsen RW (1999) $\mathrm{GABA}_{\mathrm{A}^{-}}$ receptor-associated protein links $\mathrm{GABA}_{\mathrm{A}}$ receptors and the cytoskeleton. Nature 397:69-72.

Wardell CF, Bornstein JC, Furness JB (1994) Projections of 5-hydroxytryptamine-immunoreactive neurons in guinea-pig distal colon. Cell Tissue Res 278:379-387.

Zhou X, Galligan JJ (1996) P2X purinoceptors in cultured myenteric neurons of guinea-pig small intestine. J Physiol (Lond) 496:719-729.

Zhou X, Galligan JJ (1998) Nonadditive interaction between nicotinic cholinergic and P2X purine receptors in guinea-pig enteric neurons in culture. J Physiol (Lond) 513:685-697. 